\title{
Remittances and Economic Growth in a Small and Volatile Economy
}

\author{
Morad Abdel-Halim ${ }^{1, *}$, Adel Bino ${ }^{2}$ \\ ${ }^{1}$ General Budget Department, Ministry of Finance, Amman, Jordan \\ ${ }^{2}$ Department of Finance, University of Jordan, Amman, Jordan \\ Email address: \\ abdalhalim.morad@gmail.com (M. Abdel-Halim), a.bino@ju.edu.jo (A. Bino) \\ *Corresponding author
}

\section{To cite this article:}

Morad Abdel-Halim, Adel Bino. Remittances and Economic Growth in a Small and Volatile Economy. International Journal of Business and Economics Research. Vol. 8, No. 1, 2019, pp. 31-40. doi: 10.11648/j.ijber.20190801.15

Received: January 16, 2019; Accepted: February 27, 2019; Published: March 20, 2019

\begin{abstract}
This paper investigates the relationship between worker remittances and economic growth in a small country with volatile macroeconomic conditions (namely, Jordan). Previous research determines three main channels through which the impact of remittances can be transmitted: labor supply, capital accumulation and investment, and productivity. A historical behavior of these variables since 1976 to 2016 is analyzed and discussed in the context of the Jordanian economic structure. The Autoregressive Distributed Lag (ARDL) model that allows economic growth (measured by growth in per capita GDP) and financial development (measured by bank credit) to be affected by their lagged values and by current and lagged values of remittances (measured by remittances as percentage of GDP) is used to test for equilibrating and long-term associations between remittances and economic growth and financial development indicators. The results show that although Jordanian worker remittances represent a vital source of financial flows, they are not used to smooth consumption by receiving households and have no impact on economic growth or financial development. Instead, they lead to increase in imports and trade deficit. Thus, if reverse migration of Jordanian workers takes place, it will lead to sudden increase in skilled labor supply, which will exacerbate Jordan's unemployment problems.
\end{abstract}

Keywords: Remittances, Economic Growth, Financial Development, Trade Deficit

\section{Introduction}

Both policy makers and some economists believe that remittances are crucial for the receiving country's economic activity as they may lead to poverty alleviation, consumption smoothing, and macroeconomic stability. This belief is somewhat justified because remittances in developing countries are found positively related with household welfare but at the same time produce more volatile business cycles $[7$, $12,15]$. Yet, whether remittances have any role in economic growth or financial development remains a country-specific question $[3,8,9]$.

Compared to financial flows from industries like tourism or natural resources where a clear relation can be expected with economic growth, no such relation can be directly drawn between remittances and macroeconomic variables in general or economic growth, in particular. An obvious reason behind this is that remittances require that they be properly channeled into productive uses in order to be expected to have long-run development consequences. Extant research presents mixed results for the impact of remittances on economic growth due to the peculiarity of the country's economic factors $[14,16]$. So, determining the economic consequences of remittance flows is not straightforward because remittances can have positive or negative impacts depending not only on the structure of the economy but also on how social norms have shaped household life style. Thus, the issue remains largely an empirical question in terms of remittances sustainable impact.

To investigate the association between remittances and economic growth, this paper uses data from Jordan, which although has a small economy, is one of the top 
remittance-receiving countries with highly volatile macroeconomic environment. This makes Jordan an ideal setting to test the economic role of remittances in small and volatile economies. The analysis of remittances in this paper is undertaken on two stages: the first stage discusses the channels through which remittances can enhance or deter economic activity and how such channels are structured in Jordan while the second stage analyzes the potential impact of remittances on economic growth indicators. This paper find no evidence of equilibrating relationship between Jordanian worker remittances and economic growth or financial development while there is a positive long-run relationship between Jordanian worker remittances and imports and negative relationship with trade deficit. These results have significant policy implications, the most obvious being the clear lack or inefficiency of the channels through which remittances can lead to economic growth. The paper proceeds as follows: in the next section, this paper provide an overview of Jordan's worker remittances relative to FDI, in section three, this paper discuss the channels through which remittances can affect economic growth. In section four, the paper present the empirical results of the impact of remittances on economic growth and financial development and section five concludes the paper.

\section{Jordanian Worker Remittances: An Overview}

As of the end of 2016, Jordan ranks 23rd among the top remittance-receiving countries in the world in terms of the remittances as percentage of GDP and 32nd in terms of the dollar amount of remittances received. These ranks are down from their counterparts in 2007, which were 10th and 29th, respectively (Figure 1).

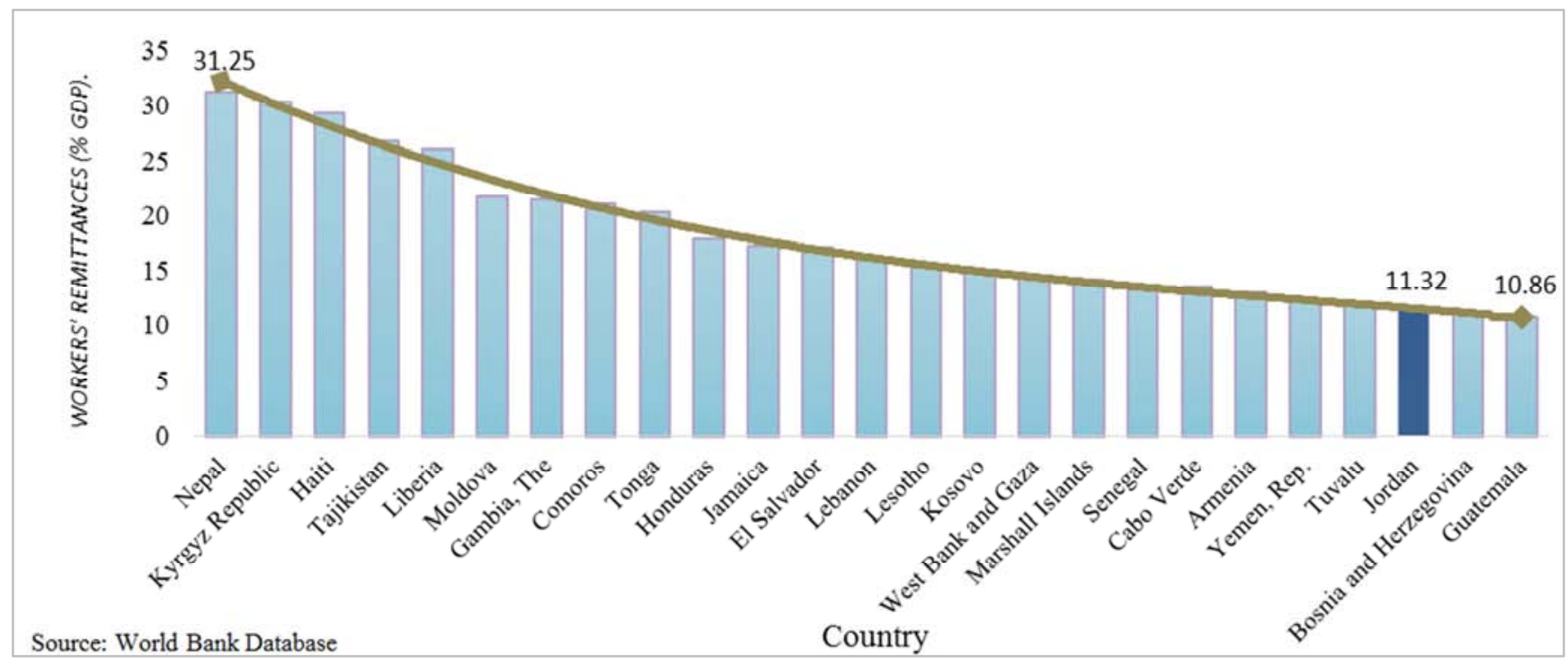

Figure 1. Workers' Remittances in 2016 (\% GDP).

As of the end of 2015, there are 559,484 Jordanian workers in the Arab Gulf region who account for almost \% 71 of all Jordanian migrants with Saudi Arabia and the United Arab Emirates (UAE) being the largest host countries of Jordanian workers and the two countries together host an estimated 450,000 Jordanians, or $\% 68$ of all Jordanian migrants [4].

Although the annual dollar amount of remittances has been stable since 2008 (between 2.46-2.69 billion JD), as percentage of GDP, it has been decreasing steadily (from $16 \%$ in 2008 to $9.6 \%$ in 2016). However, remittances to GDP is a more appropriate measure of remittances [5].

This pattern is, unfortunately, expected to continue following the economic slowdown in the Arab Gulf region driven mainly by plummeting oil prices. Jordan had witnessed similar pattern in remittances in the period leading to the huge devaluation of the Jordanian currency in 1989. Due to its resilience that was enhanced by foreign aid, the Jordanian economy had been be able to cope with the resulting economic consequences, the worst of which being rising cost of imports.

Today, however, Jordan's economy is suffering unprecedented conditions including huge influx of Syrian war refugees, high inflation and unemployment rates, and reluctance of aid granting countries to provide direct aid to government budget. These economic pressures coupled with the government debt that is lingering around $95 \%$ of GDP and the expanding trade deficit required the government to take firm actions towards economic restructuring while capitalizing on its current sources of financial flows. Jordanian workers' remittances represent one main source of financial flows besides those from tourism and exports of natural resources (mainly, phosphate and potash).

In fact, remittances are an important source of financial flows not only to Jordan but also to most of the developing countries to the extent that their economic impact can be compared to that of foreign direct investment (FDI). A simple 
comparison of remittances and FDI as percentages of GDP shows that Jordan has always received more financial flows from remittances than from FDI except in year 2006, which is the time when the government privatized many of the corporations in which it had large and controlling ownership stakes (Figure 2). Furthermore, relative to FDI, remittances are obviously more resilient and less volatile making them a stable source of financial flows that the government can rely upon as a potential driver of economic growth. The growth rate in household private consumption, which includes purchases of durable goods and services but excludes purchases of dwellings, and growth in remittances appear to follow similar pattern although the growth rate in remittances is slightly more volatile (Figure 3 ).

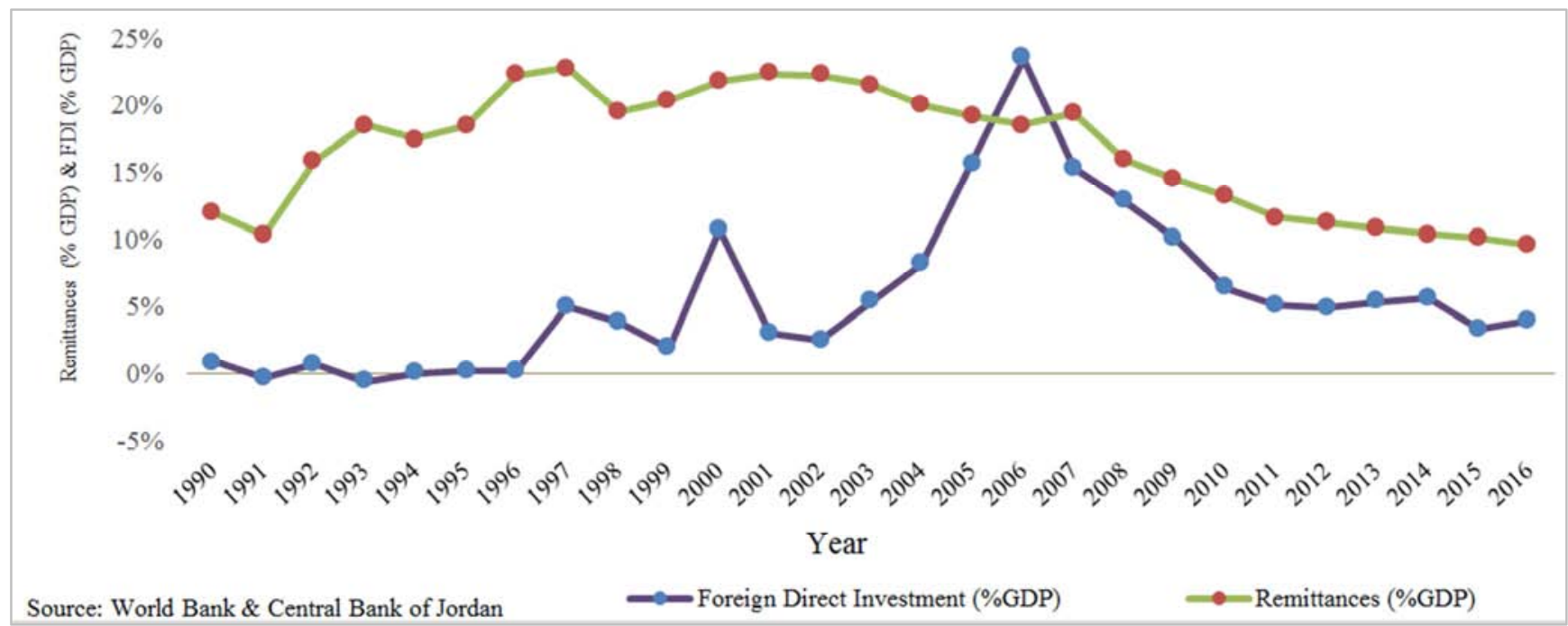

Figure 2. Remittances \& FDI (\% GDP).

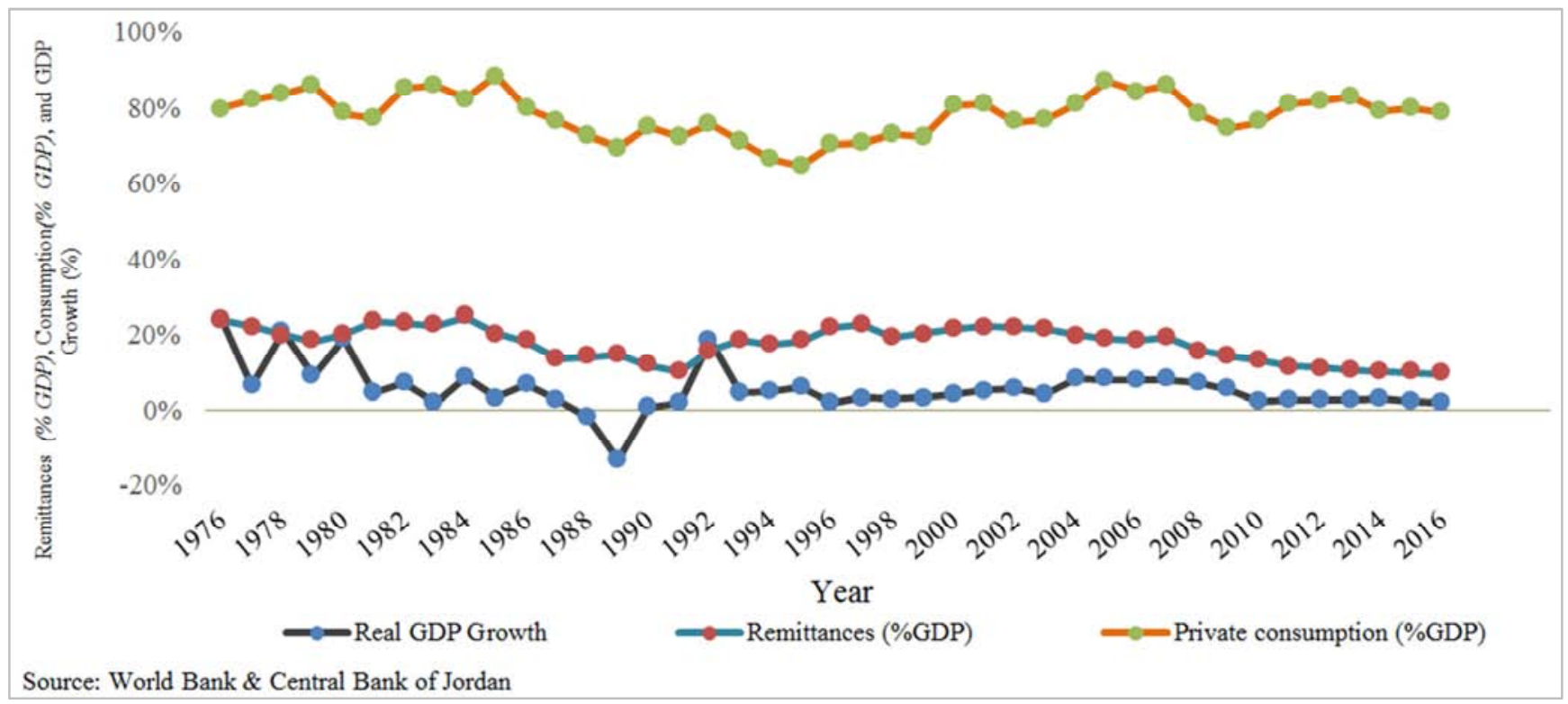

Figure 3. Remittances, Consumption, and GDP Growth.

The average growth rates of consumption and remittances are equal to $8.8 \%$ and positively correlated. However, following year 1999, many incidents of decreases in remittance flows correspond to either stable or increasing consumption rates suggesting weak evidence of remittances resulting in consumption smoothing. Besides, remittances show no clear countercyclical behavior as no significant increases (decreases) in remittances are observed during economic slowdown (growth) time periods.

\section{Channels Through Which the Impact of Remittances May Be Transmitted}

Remittances can affect economic growth through three main channels:

(1) their impact on labor supply;

(2) their impact on capital accumulation and investment;

(3) their impact on total factor productivity.

Labor supply is defined as the total number of working 
hours that individuals are willing to work at a given wage rate. The impact of remittances on individuals' willingness to participate in the labor market depends on how social norms have shaped their life-style. A consumption-oriented life-style may make remittance-receiving family members rely on funds transferred to them especially when households have high propensity to consume. Therefore, those family members may hesitate to actively engage in the labor force which results in reducing labor supply and hence, negatively affecting economic growth. In fact, theoretical and empirical evidence of negative impact of remittances on economic growth was presented in a way that indicates a sever moral hazard problem in remittances [6]. A glance at the historical behavior of labor participation rates for both males and females in Jordan (Figure 4) shows stability since 1990, about $68 \%$ and $13 \%$, on average, for males and females, respectively, with little, if any, fluctuations, a standard deviation of less than $2 \%$ for males and females.

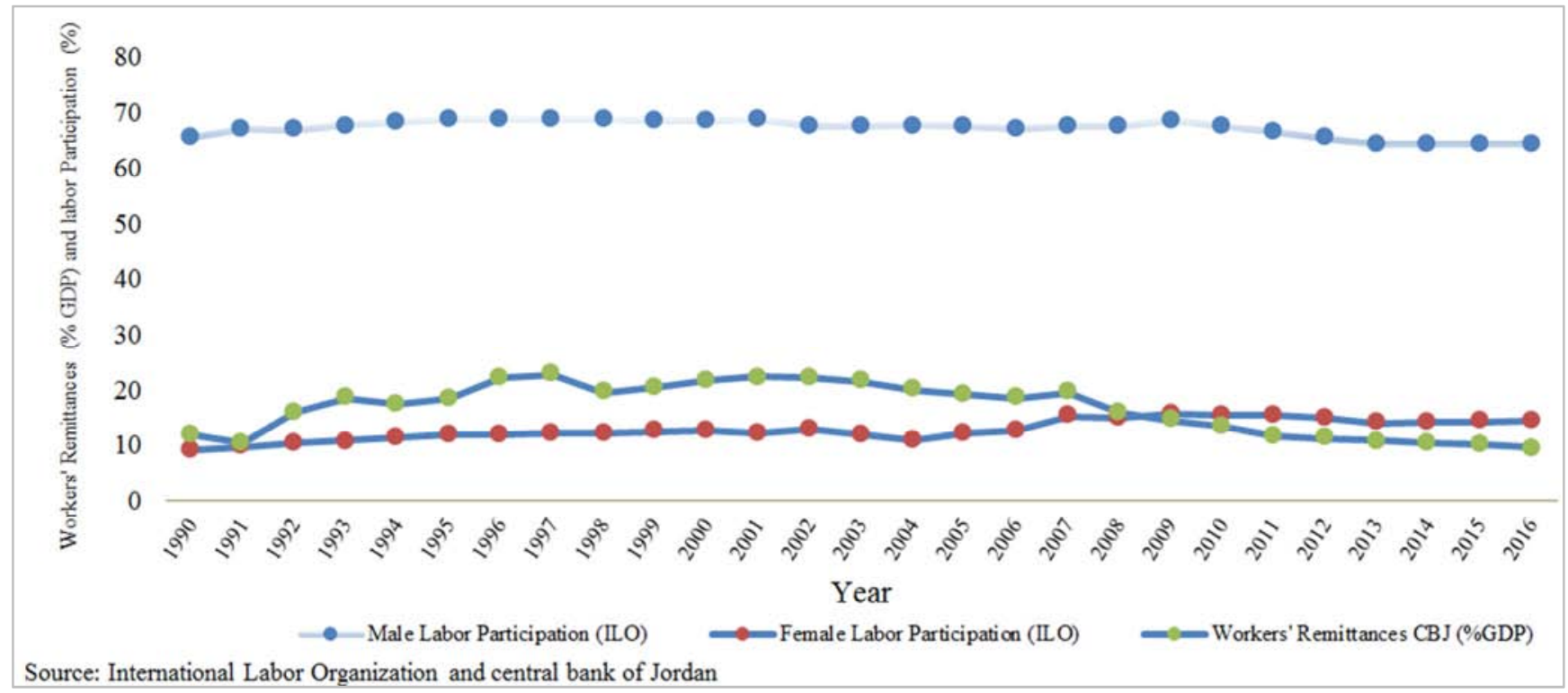

Figure 4. Remittances and labor Participation.

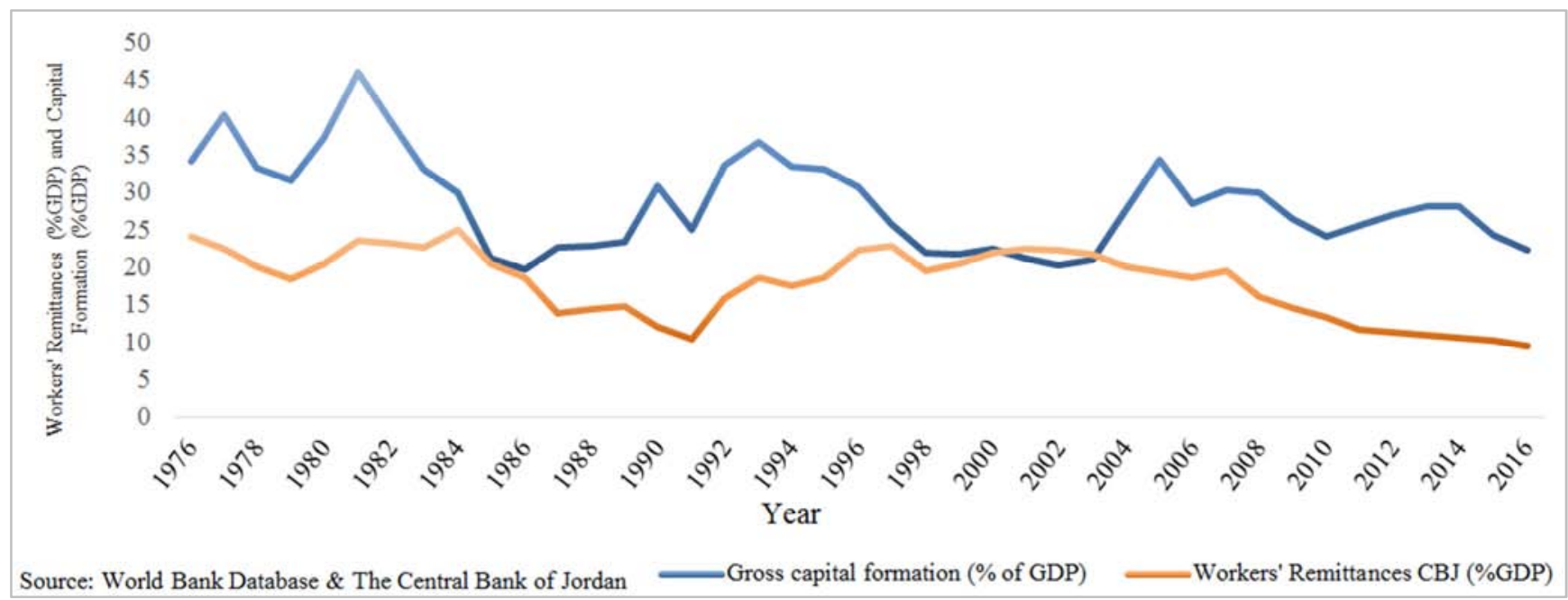

Figure 5. Remittances and Capital Formation.

Clearly, remitted funds by Jordanians do not seem to affect labor force supply negatively whether among males or females. A noticeable observation is the decrease in the percentage of remittances between 2007 and 2011 while no significant change in labor participation rates. However, if a reverse migration of Jordanian expatriates takes place, then a sudden increase in labor supply is expected, driving labor participation rates higher especially among males since those workers are highly-skilled labor. This may create a serious challenge to the government if an equivalent job creation strategy is not put in place in due time. Another and more important channel through which remittances can affect economic growth is capital accumulation and capital stock of the country which, according to the World Bank, is defined as the outlays on additions to fixed assets and inventories of goods held by corporations. Remittance-receiving countries are expected to be more able to accumulate capital and enhance investment because remittances can ease financial 
constraints that individuals face when they need funding for their investments. These financial constraints can take many forms that range from banks or credit companies placing prohibitive collateral needs against lending to imposing higher interest rates that render many investment projects unfeasible.

Thus, remittance receipts enable individuals to avoid such constraints and invest in projects that might otherwise be unfeasible. Furthermore, remittances enhance the growth in countries with less developed financial systems by providing an alternative way to finance investment and helping overcome liquidity constraints [10]. Also remittances relationship with per capita GDP is not significant statistically, remittances do have a robust and positive effect on financial development [10]. A graphical depiction of the historical behavior of gross capital formation and remittances as percentages of GDP in Jordan shows no clear association between them (Figure 5). The gross capital formation has been volatile and consistently decreasing since 2013 with almost constant percentage of remittances. This brings into question the effectiveness of available mechanisms that are ought to channel remittance flows into more investment.

On the other hand, remittances may enhance financial development because they lead to increasing the amount of funds flowing in the banking system. Thereby, financial institutions are expected to be able to reduce the cost of financial intermediation and depositors can force the government to undertake banking reforms to ease and possibly left some of the financing constraints imposed by the banking system $[10,11]$.

Financial development may also improve the efficiency of capital allocation by directing capital to its most productive use at the fair price. This, unfortunately, does not seem to be the case for Jordan. The historical behavior of remittances and bank credit as percentages of the GDP does not show any likely association between them (Figure 6) and the results of statistical tests of the relationship between them shows no significance. Remittances may also help corporations reduce the cost of both forms of capital (debt and equity) because remittance-receiving individuals may choose to invest in public corporations rather undertaking investments on their own. More remittance flows simply means more funds available for investment as long as both the government and public corporations are able to attract individuals' wealth by properly structuring a mechanism and a market where individuals can expect real increase in their wealth that results from rational investment in real assets. One way to learn whether public corporations are generating new wealth from the use of real assets is to look at the stock market performance. The market return in Amman Stock Exchange has been negative since 2006 indicating deterioration of wealth. This alarming observation of an average of about $5 \%$ negative return from the market calls for urgent structural reforms aimed at a pricing mechanism that is fair and representative of the corporations' fundamentals.

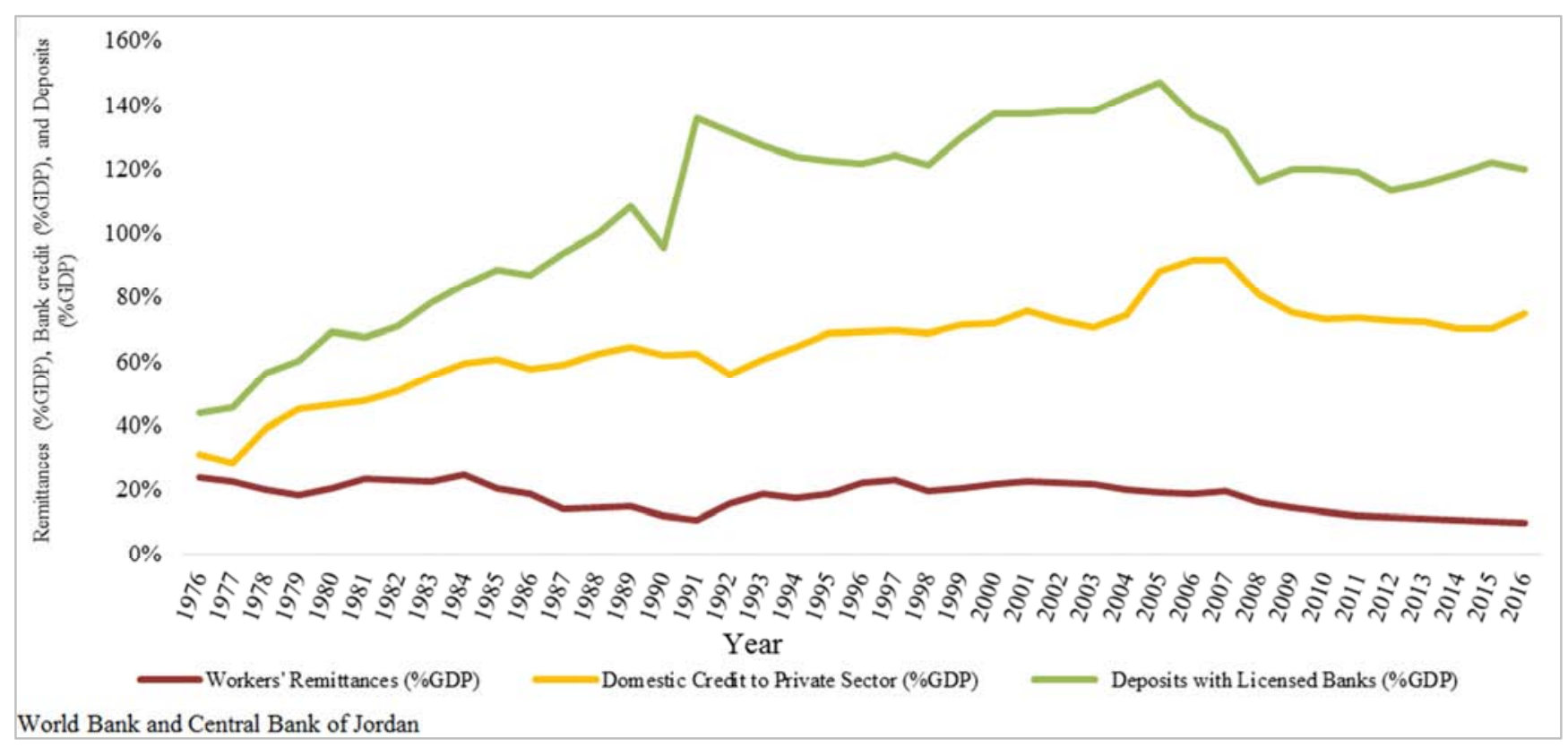

Figure 6. Remittances, Bank credit, and Deposits.

Remittances may also contribute to macroeconomic stability. If remittance flows are stable, permanent, and countercyclical, then, GDP growth is expected to be less volatile [11]. As a result, the risk premium required by corporations may decrease making corporations attracted to investments that might have been deemed too risky [5]. As previously noted, remittance flows of Jordanians have been stable for relatively long period of time with no clear countercyclical behavior but the growth in per capita GDP continues to exhibit high volatility compared to the low average growth rate that has been ranging between $-2.83 \%$ to $3.65 \%$ over the last ten years. The pro-cyclical behavior of remittances is evidenced by the positive and relatively high correlation between per capita GDP and remittances of $43 \%$. Thus, further efforts by the government are needed to determine and limit macroeconomic destabilizers. 
The third channel through which remittances may affect economic growth is the total factor productivity, which represents the portion of output not explained by the inputs of labor and capital used in production. Remittances can affect growth through enhancing total factor productivity in a way that generates production externalities by transforming remittances from just being receipts to becoming capital inflows. The economy's ability to accomplish this depends on many factors that are specific to each country. One such factor is whether the investment decision making individual has the information and the skills necessary to make rationale and informed investment decision. If this decision is made by a family member, who may not have an information advantage, rather than by a bank or a specialized financial intermediary, then no change in total factor productivity can be expected.

On the other hand, in countries that use fixed exchange rate systems remittances may adversely affect economic growth because remittance flows may lead to appreciation in the equilibrium real exchange rate [1]. This result is a characteristic of Dutch disease, which may occur because higher real household income leads to increase in aggregate demand causing increases in prices of non-tradable goods like services and move more resources to non-tradable goods industries relative to tradable goods industries like agriculture and manufacturing [1]. This Dutch disease is likely to have happened in Jordan not because the average household has become wealthier (as evidence by the negative growth in per capita GDP) but rather because the percentage of household income spent on non-durable goods relative to tradable goods has increased. Besides, most of the tradable goods are imported and not manufactured in the domestic market.

Another possible adverse impact of remittances is that they may increase the government's maximum sustainable ratio of debt to GDP because remittances can increase tax revenues even if remittances are not taxed, an example is sales tax revenues, and/or remittances may enable the government to increase the tax rate on household taxable income [5]. This is a very likely impact of remittances in Jordan because Jordan's public debt has been excessively increasing since 2009 .

Because remittances represent a source of income to households that is independent of domestic production, individuals may become less incentivized to monitor government's policy performance [11]. This may lead to inefficiency in the corporate governance mechanisms of publicly traded corporations as well.

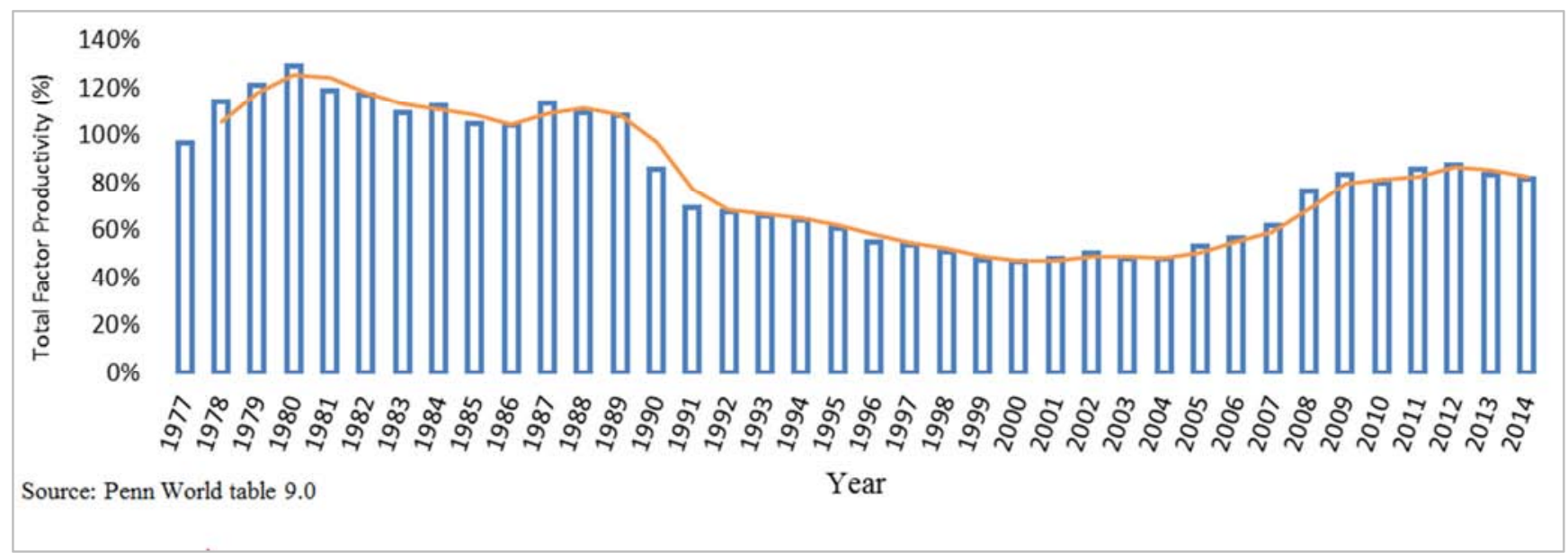

Figure 7. Total Factor Productivity (Jordan).

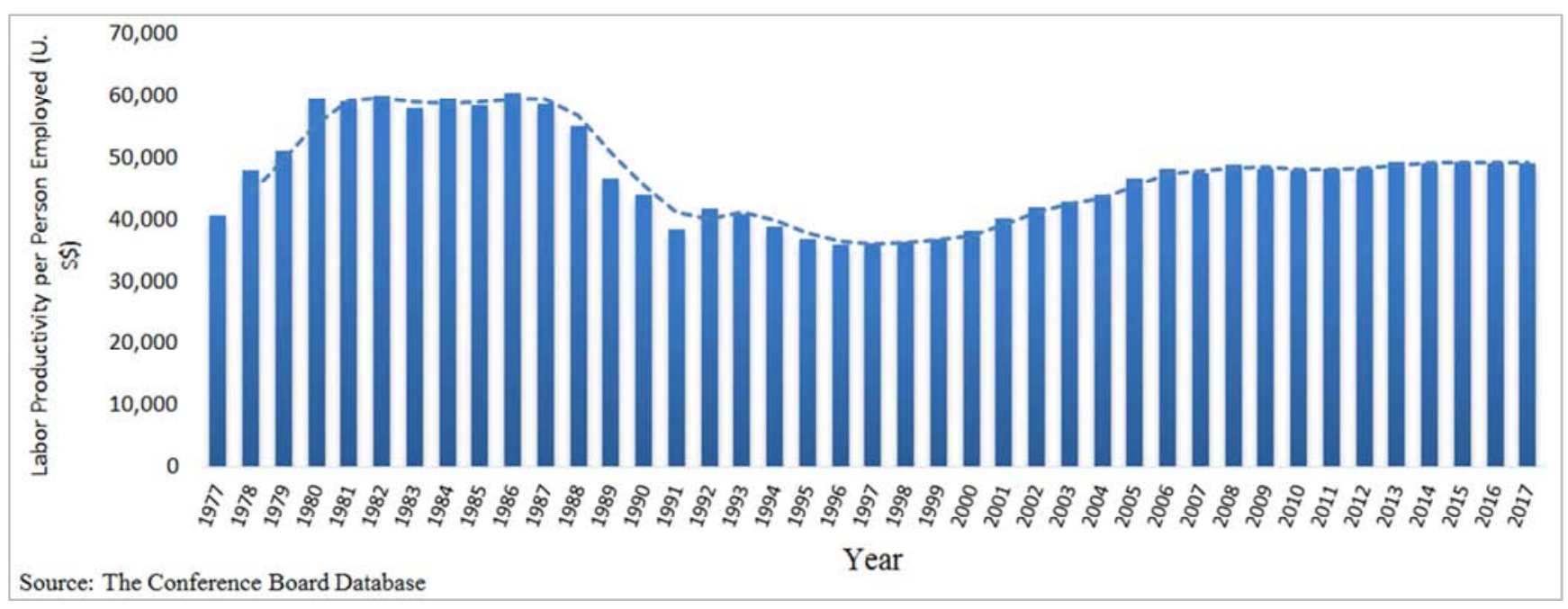

Figure 8. Labor Productivity per Person Employed (U. S\$) (Jordan). 
The overall impact of remittances on total factor productivity, if any, should be seen as improvements in the historical values of TFP. The growth in TFP consider as a source of economic growth and the lack of efficiency enhancing effect of TFP would make the net effect of TFP on economic growth ambiguous [17]. As shown in the (Figure 7), TFP has been stable since 2009, between 0.82-0.88, suggesting low and persistent technological capacity. To disentangle the role of capital from that of labor in determining TFP, the historical values of labor productivity are also reported (Figure 8). Labor productivity per person employed has been almost constant, between U. S\$ 48,000 and U. S\$ 49,000 per year for last 10 years.

Thus, it can be argued here that capital technological capacity has been volatile. These values of TFP suggest no impact of remittances, which raises many concern about the efficacy of the mechanisms that are supposed to improve productivity. These include: providing relevant investment advice to Jordanian expatriates, enhancing the ability and willingness of the financial sector, in general, and banks, in particular, to expand their credit provision activity especially credit directed to financing productive projects, improving tradable goods industries and avoiding movement of resources away from such industries.

\section{Empirical Results}

As shown in (Figure 9) and table 1, the growth rate in the real per capita GDP in Jordan, which measures the output produced by the economy per individual adjusted for inflation, has ranged between $17.84 \%$ in 1978 and $-17.08 \%$ in 1989 with an average of $1.37 \%$ and standard deviation of $5.65 \%$, indicating a highly volatile behavior especially for the time period preceding 1993 After 1993 "following previous research, the main measure of economic growth is the growth in per capita GDP see for example [5, 10]", the standard deviation of per capita GDP growth is significantly lower $(2.59 \%)$ but still more than twice the average growth rate of less than $1 \%$. Thus, Jordanian economy remains slowly growing and highly volatile due to the numerous uncertainties posed not only by local economic pressures like high government debt that exceeded $94 \%$ of GDP and persisting trade deficit that exceeded 10 billion dollars in 2014 but also regional economic and political problems in neighboring countries upon which the Jordanian economy was dependent.

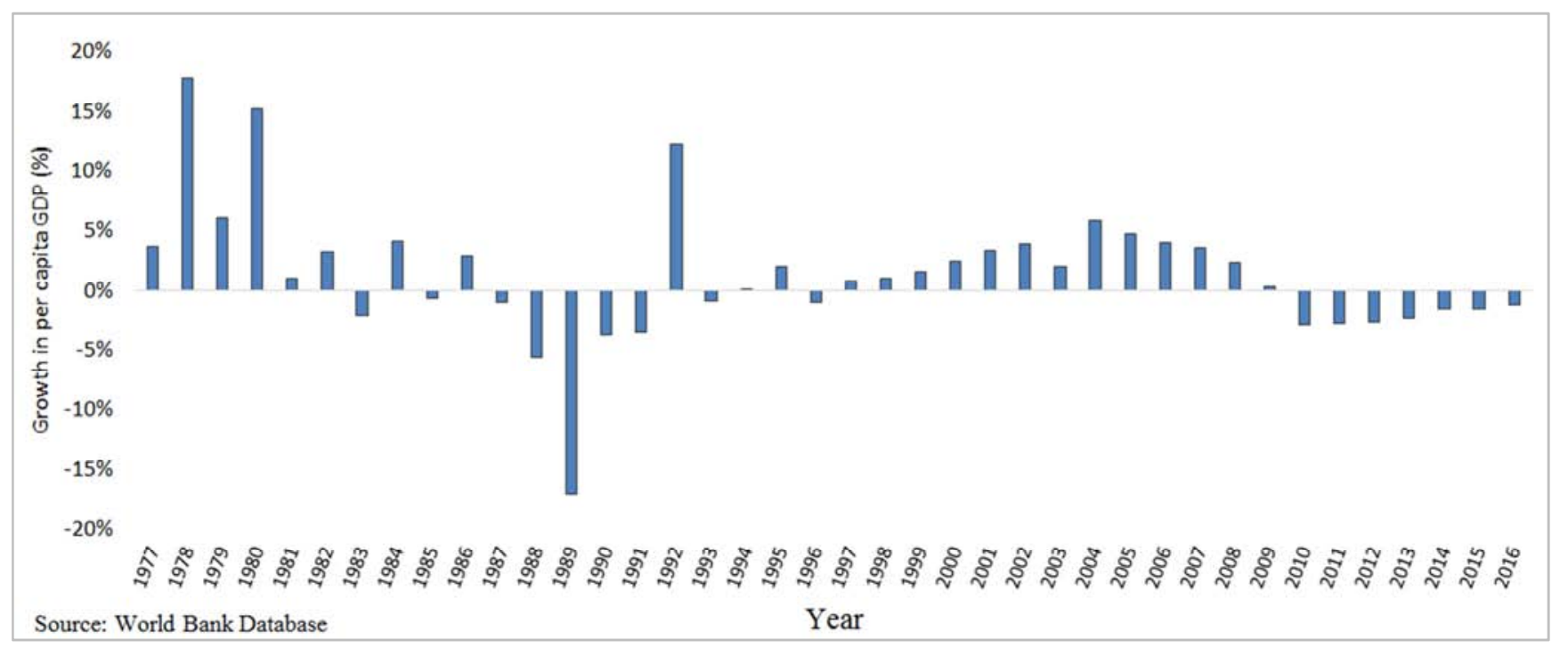

Figure 9. Growth in per capita GDP (Jordan).

Examples of such regional problems include the inability to export Jordanian products to Iraq due to the political unrest there and the Syrian war that made the cost of shipping Jordanian products to Europe more costly besides the burden that it has put on government expenditures to support Syrian refugees. A more important and probably more threatening problem facing Jordanian economy is the economic slowdown in Saudi Arabia, which was one of the largest markets for Jordanian products and main aid provider besides being the host of the largest number of Jordanian workers, that resulted in halting many projects by the Saudi government and imposing new taxes. Consequently, many employees were laid off and many others quit their jobs due to the recent taxes imposed on foreign workers of which many are Jordanian.

Table 1. Descriptive statistics: All variables are measured using data from 1977-2016 except for the labor participation variables were the data start from 1990.

\begin{tabular}{llll}
\hline Variable & Mean & Median & Standard deviation \\
\hline Real per capita GDP (J.D) & 1146.46 & 1157.34 & 160.81 \\
Per capita GDP growth & 1.37 & 1.00 & 5.65 \\
Remittances (\% GDP) & 17.70 & 18.56 & 4.49 \\
Trade deficit (\% GDP) & 37.00 & 37.29 & 9.01 \\
\hline
\end{tabular}




\begin{tabular}{llll}
\hline Variable & Mean & Median & Standard deviation \\
\hline Imports (\% GDP) & 59.74 & 59.25 & 10.22 \\
Exports (\% GDP) & 22.75 & 23.19 & 7.00 \\
Private consumption (\% GDP) & 78.22 & 78.66 & 5.84 \\
Bank credit (\% GDP) & 65.7 & 9.49 & 13.1 \\
Growth in bank credit & 12.84 & 119.91 \\
Bank deposits (\% GDP) & 110.45 & 27.97 \\
Gross capital formation (\% GDP) & 28.41 & 2.32 \\
Growth in Gross Capital Formation (\%) & 5.07 & 0.81 \\
Total factor productivity & 0.81 & 47,650 \\
Labor Productivity per person (U.S\$) & 46,933 & 6.32 \\
Male labor participation rate (\%) & 67.27 & 6.64 \\
Female labor participation rate (\%) & 12.81 & 17.64 \\
\hline
\end{tabular}

The vulnerability of the Jordanian economy to external trade shocks is evident from the significant percentage of its imports that represent almost three times its exports $(59.74 \%$ in imports versus $22.75 \%$ in exports) which results in trade deficit of more than one third of the GDP. Although the banking sector extends credit of more than $65 \%$ of GDP, it first, remains about half the amount of bank deposits and second, most of the bank credit is consumer lending than corporate lending. The large amount of bank deposits relative to GDP and the relatively low percentage of bank credit suggests that the banking sector has the ability to fund investment needs.

The augmented Dickey-Fuller stationarity tests show that the per capita GDP growth, private consumption, bank credit, and the growth in bank credit are stationary while remittances, trade deficit, imports, and bank deposits are integrated of order 1 .

Since the variables are integrated of order 0 or 1 , the following Autoregressive Distributed Lag (ARDL) model is used to estimate the relationship between worker's remittances and the dependent variables:

Table 2. Stationarity tests.

\begin{tabular}{lll}
\hline Variable & Augmented Dickey-Fuller test statistic & Probability \\
\hline Per capita GDP growth & -4.118134 & Result \\
Remittances (\%GDP) & -1.989012 & 0.0026 \\
Trade deficit & -3.984743 & 0.0460 \\
Imports & -4.618896 & 0.0183 \\
Private consumption & -4.008707 & 0.0006 \\
Bank credit & -4.972220 & 0.0165 \\
Growth in bank credit & -5.020048 & 0.0003 \\
Bank deposits & -3.938320 & 0.0018 \\
\hline
\end{tabular}

$\Delta y_{t}=a_{0}+a_{1} t+b_{0} y_{t-1}+b_{1} x_{t-1}$

$$
+\sum_{i=1}^{p-1} c_{0, i} \Delta y_{t-i}+\sum_{l=1}^{q-1} c_{l} \Delta x_{t-l}+d \Delta x_{t}+\epsilon_{t}
$$

Where $x_{t}$ is the growth rate in remittances as percentage of GDP for year $t, y_{t}$ is the growth rate in the dependent variable indicated by each specification, $\mathrm{a}_{0}$ and $\mathrm{a}_{1}$ are the estimates of the constant and trend, respectively, $\mathrm{b}_{0}, \mathrm{~b}_{1}, \mathrm{c}_{0, \mathrm{i}}, \mathrm{c}_{1}$, and $\mathrm{d}$ are parameter estimates, and $\epsilon_{\mathrm{t}}$ is an $\mathrm{i}, \mathrm{i}, \mathrm{d}$ random error.

The specification of the error correction term is given by,

$$
E C_{t}=y_{t}-\frac{b_{1}}{b_{0}} x_{t}
$$

The null hypothesis is,

$$
H_{0}: b_{0}=b_{1}=0
$$

The bound test results in Table 3 show no equilibrating relationship between the growth in per capita GDP or bank credit and economic growth while there is an equilibrating relationship between imports or trade deficit and economic growth. The Cusum stability test graphs in (Figure 10) show that the ARDL models of table 3 are stable. For the period 1971-1997, remittances have positive impact on output in Jordan with relatively strong growth generating capacity of remittances [13]. However, the growth generating capacity of rising remittances is much weaker than the growth destroying capacity of falling remittances.

Table 3. All ARDL specifications allow for up to 10 lags for both the dependent and independent variables. All specifications are checked for serial correlation and heteroscedasticity problems and model stability. The minimum and maximum bound test critical values are at the 5\% significance level.

\begin{tabular}{lllll}
\hline Dependent variable & F-statistic & Minimum critical value & Maximum critical value & Result \\
\hline Per capita GDP growth & 0.908386 & 3.15 & 4.11 & No equilibrating relationship exists \\
Imports & 4.203278 & 3.15 & 4.11 & Equilibrating relationship exists \\
Trade deficit & 8.637920 & 3.15 & 4.11 & Equilibrating relationship exists \\
Bank credit & 3.665507 & 6.56 & 7.3 & No Equilibrating relationship exists \\
\hline
\end{tabular}




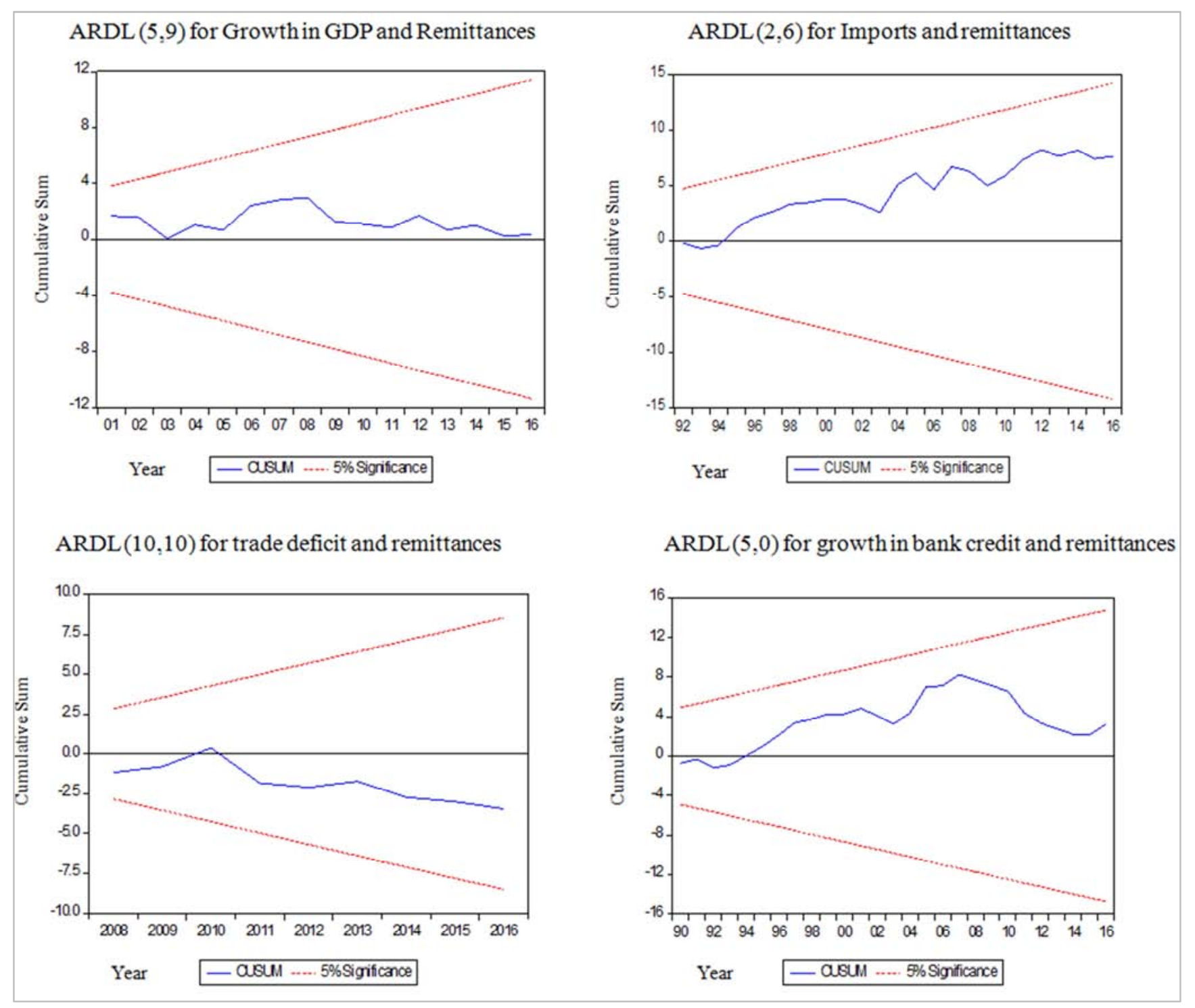

Figure 10. Cusum model stability test graphs of the ARDL models of remittances and the dependent variables.

Table 4. Long-run coefficients of the Autoregressive distributed lag (ARDL) model: The independent variable in the specifications is the remittance as percentage of GDP.

\begin{tabular}{lll}
\hline Dependent variable & Long-run coefficient & Significance level \\
\hline Trade deficit & -1.830277 & 0.00 \\
Imports & 3.083287 & 0.00 \\
\hline
\end{tabular}

The long-rum coefficients in Table 4 show a significant positive impact of remittances on imports and significant negative impact of remittances on trade deficit. These results further emphasize Jordan's dependence on imported goods which leads to sustained trade deficit that further worsened by the inability to channel remittance cash flows into local investments. For the period 1971-1997, there is no impact of remittances on imports in Jordan [13]. In addition, there is no impact of remittances on financial development [2]. As shown in Table 5, the negative and equilibrating relationship between remittances and trade deficit adjusts more than five times faster than the adjustment in the positive and equilibrating relationship between imports and economic growth.
Table 5. Speed of adjustment of errors in equilibrium between remittances and each of the dependent variables to long-run equilibrium levels.

\begin{tabular}{lll}
\hline Dependent variable & Speed of adjustment & Significance level \\
\hline Trade deficit & $109.16 \%$ & 0.00 \\
Imports & $22.09 \%$ & 0.00 \\
\hline
\end{tabular}

\section{Conclusions}

Whether cash flows from remittances to receiving countries drive their economic growth remains a largely debated and unresolved question in the literature. Previous research presents evidence on both ends but agree that results are dependent on country-specific macro and micro variables. This paper investigate that question in a small and volatile country.

This paper found that remittances in Jordan do increase household disposable income and possibly leads to poverty alleviation. However, due to the inefficiency of the mechanisms through which remittance flows may be 
transformed into productive uses, remittances have no impact on financial development and/or economic growth. Instead, the results show that remittance inflows in Jordan significantly increase imports that, due to no change in exports, worsens Jordan's trade deficit. The results are unlikely to be driven by data distortions, model misspecifications, or time-variant instabilities. However, it is still possible that remittances enhance the central government's borrowing capacity because during the last ten Jordan's sovereign debt has more than tripled, contributed to preserving stable reserves, and/or expanded the informal economy. Thus, further research is needed to investigate these issues and provide pertaining policy implications.

\section{References}

[1] Acosta, Pablo A., Emmanuel K. K Lartey, and Fredrica Mandelman, (2008), "Remittances, Exchange Rate regimes, and the Dutch Disease: A panel data Analysis," Federal Reserve Bank of Atlanta Working Paper No. 2008-12 (Atlanta: Federal Reserve Bank).

[2] Aggarwal, R., Demirguc-Kunt, A. and Martinez Peria, M. (2006). "Do Remittances Promote Financial Development?" Evidence from a Panel of Developing Countries." World Bank mimeo.

[3] Barajas, Adolfo, Ralph Chami, Connel Fullenkamp, Michael Gapen and Peter Monteil, (2009), "Do Workers' Remittances promote Economic Growth?" IMF Working Paper 09/153 (Washington: International Monetary Fund).

[4] Bel-Air, F. (2016), "Migration Profile: Jordan", Robert Shuman Center for Advanced Studies, Migration Policy Center.

[5] Chami, Ralph, Adolfo Barajas, Thomas Cosimano, Connel Fullenkamp, Michael Gapen, and Peter Montiel, (2008a), Macroeconomic Consequences of Remittances, IMF Occasional Paper No. 259 (Washington: International Monetary Fund).

[6] Chami, R., C. Fullenkamp, and S. Jahjah, (2003), “Are Migrant Remittance Flows a Source of Capital for Development?" IMF Working Paper, International Monetary Fund, Washington D. C.
[7] Chami, Ralph, Thomas F. Cosimano, and Michael T. Gapen, (2008b), "Beware of Emigrants Bearing Gifts: Optimal Fiscal and Monetary Policy in the Presence of Remittances," IMF Working Paper 06/61 (Washington: International Monetary Fund).

[8] Fayissa, B., \& Nsiah, C. (2010). The Impact of Remittances on Economic Growth and Development in Africa. The American Economist, 55(2), 92-103.

[9] Ghosh Dastidar, S. (2017). Impact of Remittances on Economic Growth in Developing Countries: The Role of Openness. Global Economy Journal, 13(1), pp. -. Retrieved 23 Jan. 2019, from doi:10.1515/gej-2016-0066.

[10] Giuliano, Paola, and Marta Ruiz-Arranz (2009). "Remittances, financial development, and growth." Journal of Development Economics 90.1: 144-152.

[11] Hakura, M. D., Chami, M. R., \& Montiel, M. P. (2009). Remittances: an automatic output stabilizer? (No. 9-91). International Monetary Fund.

[12] Nsiah, C. and Fayissa, B. (2013), "Remittances and economic growth in Africa, Asia, and Latin American-Caribbean countries: a panel unit root and panel cointegration analysis", Journal of Economics and Finance, Vol. 37 No. 3, pp. 424-441.

[13] Nicholas P. Glytsos, (2005) "The contribution of remittances to growth: A dynamic approach and empirical analysis", Journal of Economic Studies, Vol. 32 Issue: 6, pp.468-496.

[14] Pradhan, Gyan., Mukti Upadhyay, and Kamal Updhyaya, (2008), "Remittances and economic Growth in Developing Countries," The European Journal of Development Research, 20.3: 497-506.

[15] Richard H. Adams JR (2011) Evaluating the Economic Impact of International Remittances On Developing Countries Using Household Surveys: A Literature Review, Journal of Development Studies, 47:6, 809-828.

[16] Ruiz, Isabel, Elias Shukralla, and Carlos Vargas-Silva (2009). "Remittances, institutions and growth: a semi parametric study". International Economic Journal 23.1: 111-119.

[17] Senbeta, Aberra (2013), Remittances and the sources of growth, Applied Economics Letters, 20:6, 572-580, DOI: 10.1080/13504851.2012.718057. 